\title{
Enzymatic Synthesis of Butyl Ferulate by Silica-Immobilized Lipase in a Non-Aqueous Medium
}

\author{
Chandresh Chandel, Ashok Kumar, Shamsher S. Kanwar
}

Department of Biotechnology, Himachal Pradesh University, Shimla, India. Email: kanwarss2000@yahoo.com

Received March $18^{\text {th }}$, 2011; revised June 20 ${ }^{\text {th }}$, 2011; accepted August $15^{\text {th }}, 2011$.

\begin{abstract}
Butyl ferulate was synthesized using a silica-immobilized commercial lipase (Steapsin) in dimethylsulfoxide (DMSO). Lipase-immobilized by surface adsorption onto silica pretreated with $1 \%$ glutaraldehyde showed $89 \%$ binding of protein. The esterification of butanol $(100 \mathrm{mM})$ and ferulic acid $(50 \mathrm{mM})$ by silica-bound biocatalyst was carried out at $45^{\circ} \mathrm{C}$ for $6 \mathrm{~h}$ under shaking $(120 \mathrm{rpm})$. The optimization of various reaction conditions like molar concentration of reactants, biocatalyst concentration, reaction time, temperature, addition of molecular sieves, salt ions, and repetitive bio-catalysis in DMSO were studied, consecutively. The bound lipase $(15 \mathrm{mg} / \mathrm{ml})$ catalyzed the esterification of ferulic acid and butanol with a yield of $64 \mathrm{mM}$ under optimized reaction conditions. Among the salt ions $\mathrm{Cu}^{2+}, \mathrm{Zn}^{2+}$ and $\mathrm{Al}^{3+}$ ions moderately promoted the ester yield (66 $\mathrm{mM}$ ) while $\mathrm{Mg}^{2+}, \mathrm{NH}_{4}{ }^{+}, \mathrm{Fe}^{2+}$ and $\mathrm{Ca}^{2+}$ were found to decrease the ester yield. The by-product $\left(\mathrm{H}_{2} \mathrm{O}\right)$ produced in the reaction was scavenged by the molecular sieves $(10 \mathrm{mg} / \mathrm{ml})$ added to the reaction mixture, which enhanced the formation of ester up to $74 \mathrm{mM}$. During the repetitive reactions, the bound lipase produced $32 \mathrm{mM}$ ester after $4^{\text {th }}$ cycle of esterification. On scaling-up the reaction volume to $30 \mathrm{ml}, 32.5 \mathrm{mM}$ butyl ferulate was synthesized under optimized conditions.
\end{abstract}

Keywords: Silica, Glutaraldehyde, Butyl Ferulate Synthesis, Molecular Sieves

\section{Introduction}

The lipases (EC 3.1.1.3.) are becoming increasingly attractive in the pharmaceutical, cosmetic and oil industry due to their stability, especially selectivity and successful biotransformation. Currently, scientists are making efforts to evolve newer derivatives of natural plant products that are more amenable as emoluments, constituents of cosmetics, toiletries and fragrances etc. Such products of plant origin are likely to be better acceptable for human use with least side effects or cytotoxicity. Esters of cinnamic acid, ellagic acid, ferulic acid etc. are organic compounds of biotechnological relevance that could be suitable modified as flavor/fragrance compounds, precursors of pharmaceuticals and as additives in foods, cosmetics and sun-screens. Ferulic acid (4-hydroxy-3-methoxy cinnamate) is an effective antioxidative agent among various hydroxycinnamic acids as it potentially prevents the autoxidation of linoleic acid in the ethanolbuffer system [1]. Moreover, esters of ferulic acid are easy to apply on skin and show an increased antioxidant activity instead of use of ferulic acid that has an acidic nature and as such cannot be spread on the skin. The activity of alkyl ferulate is somewhat influenced by the chain length of alcohol moiety [2]. Comparing the effects of ferulic acid and its esters, hexyl, octyl and 2-ethyl-1hexyl ferulates were significantly more active than ferulic acid itself, and higher or lower carbon chain homologues than hexyl and octyl ferulates were less active as anti-oxidant molecules [1,3]. Ethyl ferulate that is widely distributed in plants possesses a UV absorbance maximum at $\sim 320 \mathrm{~nm}$ [4]. Ferulic acid is believed to suppress melanin generation by antagonizing tyrosine because its chemical structure is similar to tyrosine; and it effectively absorbs harmful long wave ultraviolet radiations emerging from the Sun. Ferulic acid and its esters are well known "oxidation inhibitors".

Butyl ferulate exhibits free radical scavenging activity against DPPH radicals [1]. Also the same compound was reported to play a chemopreventive role in cancer by inducing tumor cells apoptosis. A significant cytochromec 
release has been found when treating TM-3 cells with butyl ferulate [5]. In the light of the aforesaid an attempt was made to synthesize butyl ferulate using a silicabound commercial lipase "Steapsin". Most common cinnamic acids and short-chain esters are water soluble, limiting their usefulness as waterproof sunscreens but ferulic acid is insoluble in water and its derivatives therefore have been designed with long-chain hydrocarbons (e.g., octyl-p-methoxy cinnamate), which renders them water-insoluble and suitable for waterproof sunscreens [6]. The $-\mathrm{OCH}_{3}$ group of octyl-p-methoxy cinnamate acts as an electron-releasing group to improve the electron excitation process [7]. When triolin ferulate was combined with ferulyl-substituted oleins, it elevated the UV absorptivity of a cinnamate ester with the water- insoluble properties of a lipid [8]. The lipase-catalyzed transesterification of ethyl ferulate with ethanol could potentially lead to new sunscreen products, synthesized from natural products, while providing a value-added use for vegetable oils [9-11].

Ferulic acid that has little solubility in most alkanes and aqueous media could be solublized in DMSO or diethyl phthalate to achieve ester synthesis or trans-esterification $[12,13]$. The immobilized enzymes are preferred for biocatalysts because of obvious easy recovery, increased stability at raised temperature and or $\mathrm{pH}$ as well as repetitive use in reaction system(s). The current work focuses on the synthesis of butyl ferulate from butyl alcohol and ferulic acid by employing immobilized-lipase under optimized reaction conditions such as catalyst loading, mole ratio, temperature, $\mathrm{pH}$, effect of salt ions, molecular sieves and repetitive use of silica-bound lipase.

\section{Material and Methods}

Ferulic acid and butanol were procured from Merck Schuchardt, Germany. DMSO from Sigma Aldrich, USA; and molecular sieves $3 \AA \times 1.5 \mathrm{~mm}$ were from E. Merck (India) Ltd., Mumbai. Commercial lipase: Steapsin was obtained from Sisco Research Laboratory, Mumbai, India; and silica 100 - 200 mesh was from s-d fine Chemicals, Mumbai, India. All chemicals were of analytical grade and were used as received.

\subsection{Determination of Lipase Activity}

The activity of free and immobilized Steapsin was measured by lipase assay [14] with minor modifications. The reaction mixture contained $80 \mu \mathrm{l}$ of $p$-nitrophenol palmitate ( $p$-NPP) stock solution (20 mM $p$-NPP prepared in isopropyl alcohol), $80 \mu \mathrm{l}$ of the test sample (lipase) and Tris buffer $(0.05 \mathrm{M}$, pH 8.5) to make final volume to $3 \mathrm{ml}$. The reaction mixture was incubated at $45^{\circ} \mathrm{C}$ for $10 \mathrm{~min}$ in a water-bath. The reaction was stopped by keeping the reaction mixture at $-20^{\circ} \mathrm{C}$ for 10 minutes. An appropriate control with a heat-inactivated enzyme (5 min in a boiling-water bath) was included with each assay. The absorbance of $p$-nitrophenol released in the reaction mixture was measured at $\mathrm{A}_{410}$. Each of the assays was performed in triplicate, and mean values \pm standard deviations were presented. One unit (1 IU) of lipase activity was defined as the micromoles of $p$-nitrophenol released/ minute by the hydrolysis of $p$-NPP by $1 \mathrm{ml}$ of soluble enzyme or $1 \mathrm{~g}$ of silica-bound enzyme (weight of matrix included) at $45^{\circ} \mathrm{C}$ under assay conditions. All the additives including buffer were pre-incubated at $45^{\circ} \mathrm{C}$ for short period ( $3 \mathrm{~min}$ ) before the enzyme was added to start the reaction.

\subsection{Determination of Protein Content}

Protein concentration in the free or matrix-bound lipase was determined as described previously [15] using bovine serum albumin as a standard.

\subsection{Immobilization of Enzyme onto Silica}

The matrix was washed three times with Tris buffer 0.05 $\mathrm{M} \mathrm{pH} 8.5$ to remove soluble impurities. The silica (3.5 g), pre-equilibrated in an excess volume of Tris buffer (0.05M, pH 8.5), was incubated with commercial lipase (Steapsin $3.60 \mathrm{IU} / \mathrm{ml}$ and $18.2 \mathrm{mg} / \mathrm{ml}$ protein) at $8^{\circ} \mathrm{C}$ overnight. The volume of the supernatant, amount of unbound protein, and the lipase activity were estimated. The bound-lipase activity was assayed in silica-bound lipase $20 \mathrm{mg} /$ reaction volume of $2 \mathrm{ml}$ ). The bound protein in the matrix was determined by subtraction of the unbound protein in the supernatant from the total protein used for immobilization. The silica was pretreated with a glutaraldehyde (12 ml; $1 \%$, v/v in $0.05 \mathrm{M}$ Tris $\mathrm{pH}$ 8.5) before immobilization of the lipase by adsorption $[16,17]$.

\subsection{Esterification of Butanol and Ferulic Acid}

Butyl ferulate synthesis was performed by using $100 \mathrm{mM}$ ethanol, $50 \mathrm{mM}$ ferulic acid and silica-bound lipase ( $\sim 2.95 \mathrm{IU} / \mathrm{mg}$ ) taken in $2.0 \mathrm{ml}$ of DMSO in Tefloncapped glass-vial ( $5 \mathrm{ml}$ capacity). The reaction was performed at $45^{\circ} \mathrm{C}$ for $6 \mathrm{~h}$ along with buffer-treated silica as a control under shaking (120 rpm). Each of the esterification reactions was performed in triplicate, unless otherwise stated, and the mean values and standard deviation (SD) were determined. Samples of the reaction cocktail $(10 \mu l)$ were withdrawn at intervals and analyzed by gas liquid chromatography (GLC) for presence of butyl ferulate.

\subsection{Analysis of Butyl Ferulate by GLC}

The butyl ferulate produced in the reaction cocktail was 

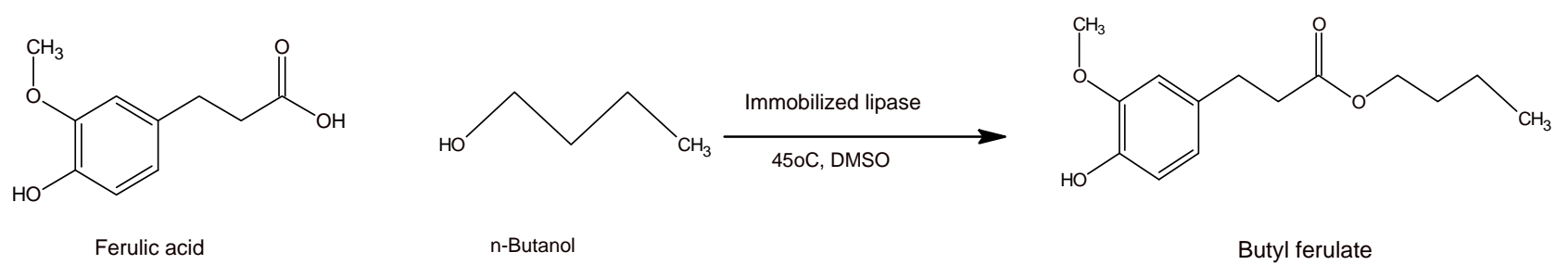

Figure 1. Lipase catalyzed esterification of ferulic acid and n-butanol to produce butyl ferulate.

analyzed by GLC equipped with a flame ionization detector and a packed type column (10\% SE-30 Chrom WHP, 2 meter length, mesh size 80 - 100, internal diameter $1 / 8$ inches, maximum temperature limit $300^{\circ} \mathrm{C}$; Netel Chromatograph, Thane, India). $\mathrm{N}_{2}$ was used as a carrier gas $\left(30 \mathrm{~cm}^{3} / \mathrm{min}\right)$. The injector was set at $260^{\circ} \mathrm{C}$; detector at $270^{\circ} \mathrm{C}$ and the column/ oven temperature was kept at $250^{\circ} \mathrm{C}$. The sample size for the GLC analysis was $2 \mu \mathrm{l}$.

\subsection{Optimization of Parameters for Synthesis of Butyl Ferulate}

The effects of various parameters such as reaction time, relative molar concentration of reactants, reaction temperature, $\mathrm{pH}$, and effect of detergents, chelating agents, salt ions and repetitive use of immobilized lipase on yield of butyl ferulate were separately evaluated. All esterification reactions were performed using $20 \mathrm{mg}$ of silicabound lipase/reaction volume $(2 \mathrm{ml})$ at $45^{\circ} \mathrm{C}$ under shaking condition (120 rpm) unless stated otherwise.

\subsubsection{Effect of Molar Concentration of Reactants}

The concentration of ferulic acid and butanol were varied one at a time $(25,50,75$ and $100 \mathrm{mM})$. The reaction was carried out for $18 \mathrm{~h}$ at $45^{\circ} \mathrm{C}$ under shaking. The subsequent esterification reactions were carried out at optimized molar concentrations of ferulic acid and butanol.

\subsubsection{Effect of Reaction Time on Synthesis of Butyl Ferulate}

The reaction mixture containing silica-bound lipase, and $100 \mathrm{mM}$ of butanol and $50 \mathrm{mM}$ ferulic acid in DMSO was incubated at $45^{\circ} \mathrm{C}$ in a water-bath-incubator shaker for $18 \mathrm{~h}$. At intervals of $2 \mathrm{~h}$, the solvent phase was sampled and analyzed by GLC for the presence of butyl ferulate. The optimized reaction time was considered in the subsequent experiments.

\subsubsection{Effect of the Biocatalyst Concentration}

The synthesis of butyl ferulate was performed by placing varying amounts of the immobilized lipase $(5-30 \mathrm{mg} / \mathrm{ml}$ in triplicates) in $2 \mathrm{ml}$ of a reaction mixture containing $100 \mathrm{mM}$ each of ferulic acid and butanol in DMSO at $45^{\circ} \mathrm{C}$ for $6 \mathrm{~h}$ under shaking. GLC analysis was done for the quantification of the butyl ferulate produced in the reaction mixture.

\subsubsection{Effect of Temperature on Ester Synthesis}

The effect of reaction temperature $(25,35,45,55$, and $65^{\circ} \mathrm{C}$ ) on the synthesis of butyl ferulate was studied in Teflon-capped glass-vials $(5 \mathrm{ml})$. The reaction mixture containing butanol, ferulic acid (100 mM:50 mM) in DMSO and silica-immobilized lipase (30 mg/reaction volume of $2 \mathrm{ml}$ ) were incubated at each of the selected temperatures for $6 \mathrm{~h}$ under shaking. The amount of ester synthesized was determined by GLC.

\subsubsection{Effect of Salt Ions on the Esterification of Ferulic Acid and Butanol.}

The effect of salt ions on the synthesis of butyl ferulate was evaluated by pre-incubating the immobilized enzyme separately with each of the salt ions $\mathrm{NH}_{4}{ }^{+}, \mathrm{Mg}^{2+}$, $\mathrm{Ca}^{2+}, \mathrm{Mn}^{2+}, \mathrm{Zn}^{2+}$ and $\mathrm{Al}^{+3}$ (1 mM in Tris buffer) for 30 $\min$ at $45^{\circ} \mathrm{C}$. The silica-bound lipase was spun down by centrifugation $(10,000 \mathrm{rpm}, 5 \mathrm{~min})$ and the buffer containing salt ion(s) was completely decanted by inversion. The sedimented bound-enzyme was washed in DMSO and spun down again to perform the esterification as above. The synthesis of butyl ferulate was recorded, thereafter.

\subsubsection{Effect of Molecular Sieves on the Synthesis of Butyl Ferulate}

The reaction mixture containing $50 \mathrm{mM}$ ferulic acid and $100 \mathrm{mM}$ butanol when incubated at $45^{\circ} \mathrm{C}$ with varying concentration of molecular sieves (10 - $200 \mathrm{mg}$ ) and to observe the effect of varying concentration of molecular sieves on the amount of ester synthesized was recorded in comparison to the control without molecular sieves.

\subsubsection{Reusability of Silica Immobilized Lipase in Continuous Cycles of Esterification.}

The immobilized lipase was used for the synthesis of butyl ferulate in DMSO, repetitively up to $4^{\text {th }}$ cycle of 6 $\mathrm{h}$ each at $45^{\circ} \mathrm{C}$ under shaking. After first cycle of esterification, the biocatalyst was recovered (by centrifuging and decanting the reaction mixture), and this biocatalyst was used to catalyze fresh esterification reaction. The reaction system contained $100 \mathrm{mM}$ of butanol and 50 $\mathrm{mM}$ of ferulic acid treated with molecular sieves (10 $\mathrm{mg} / \mathrm{ml}$ reaction volume) and the reaction was carried out under optimized conditions. 


\subsubsection{Effect of Volumetric Scale up of Reaction System on the Synthesis of Butyl Ferulate}

The volume of reaction mixture containing $50 \mathrm{mM}: 100$ $\mathrm{mM}$ ferulic acid and butanol, respectively was scaled up from initial $2 \mathrm{ml}$ to $5,10,15$ and $30 \mathrm{ml}$ with a corresponding increase in the amount of biocatalyst and the molecular sieves in the reaction system.

\section{Results}

\subsection{Immobilization of the Commercial Lipase}

A commercial lipase "Steapsin" was optimally immobilized on to silica that retained $95.3 \%$ of total protein used for immobilization. The activity of free lipase was $3.6 \mathrm{IU} / \mathrm{ml}$. After immobilization onto silica, the boundlipase exhibited 2.95 IU activity and retained approximately $98 \%$ of its original hydrolytic activity. To achieve the biocatalysis it is essential to determine the optimum values of temperature, $\mathrm{pH}$, time of reaction, and molar concentration of reactants for higher yield of products [18-20].

\subsection{Optimization of Various Reaction Parameters for Esterification Reaction}

\subsubsection{Effect of Molar Concentration of Reactants}

The maximum ester synthesis $(64 \mathrm{mM})$ was observed when concentration of ferulic acid and butanol was kept $50 \mathrm{mM}$ : $100 \mathrm{mM}$ (Figure 2). The reactant concentration above or below this ratio resulted in a decline in the synthesis of butyl ferulate. In contrast a little esterification could be achieved by immobilized lipase when concentration of ferulic acid was kept constant $(100 \mathrm{mM})$ and butanol concentration was varied from 25 to $100 \mathrm{mM}$. Thus further esterification reactions were carried out at optimized molar concentrations of ferulic acid and butanol (50 mM:100 mM, respectively).

\subsubsection{Effect of Incubation Time on Synthesis of Butyl Ferulate}

Kinetics of immobilized-lipase catalyzed synthesis of butyl ferulate was studied for $18 \mathrm{~h}$ at $45^{\circ} \mathrm{C}$ in DMSO under continuous shaking. The butyl ferulate was formed with a maximum conversion rate of approximately 64 $\mathrm{mM}$ within a short period of $6 \mathrm{~h}$ (Figure 3). Thus in the subsequent experiments reaction time of $6 \mathrm{~h}$ at $45^{\circ} \mathrm{C}$ for immobilized-lipase was considered optimum for the synthesis of butyl ferulate.

\subsubsection{Effect of the Biocatalyst Concentration}

The synthesis of butyl ferulate was performed by placing varying amounts of the immobilized lipase $(5-30 \mathrm{mg} / \mathrm{ml}$ in triplicates) in $2 \mathrm{ml}$ of a reaction mixture containing $100 \mathrm{mM}$ butanol and $50 \mathrm{mM}$ ferulic acid in DMSO at $45^{\circ} \mathrm{C}$ for $6 \mathrm{~h}$ under shaking (Figure 4). GLC analysis

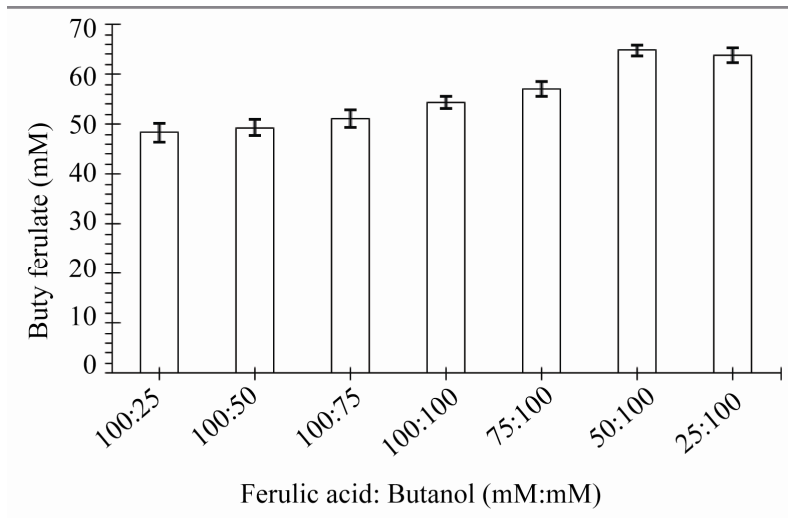

Figure 2. Effect of molar concentrations of reactants on the synthesis of butyl ferulate. The reaction mixture containing varying ratio of ethanol and ferulic acid in DMSO was incubated at $45^{\circ} \mathrm{C}$ under shaking for $6 \mathrm{~h}$.

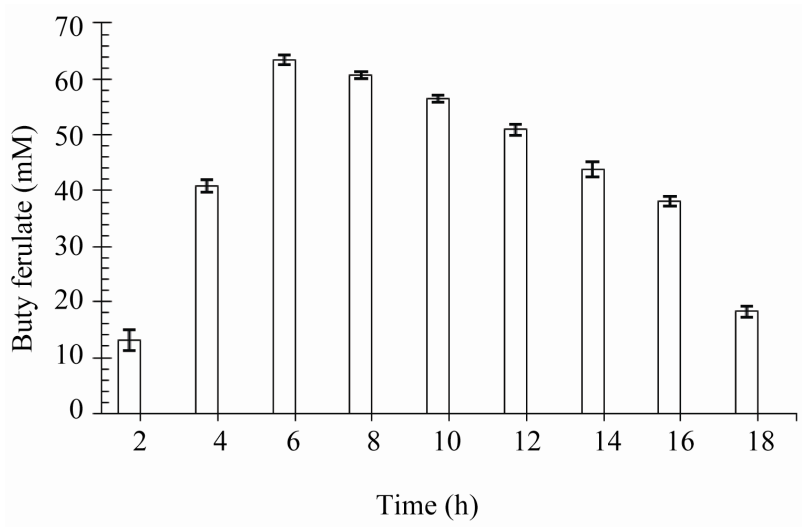

Figure 3. Effect of reaction time on the synthesis of butyl ferulate. The reaction mixture containing $100 \mathrm{mM}$ of butanol and $50 \mathrm{mM}$ ferulic acid and, silica-bound biocatalyst in DMSO was incubated at $45^{\circ} \mathrm{C}$ under shaking.

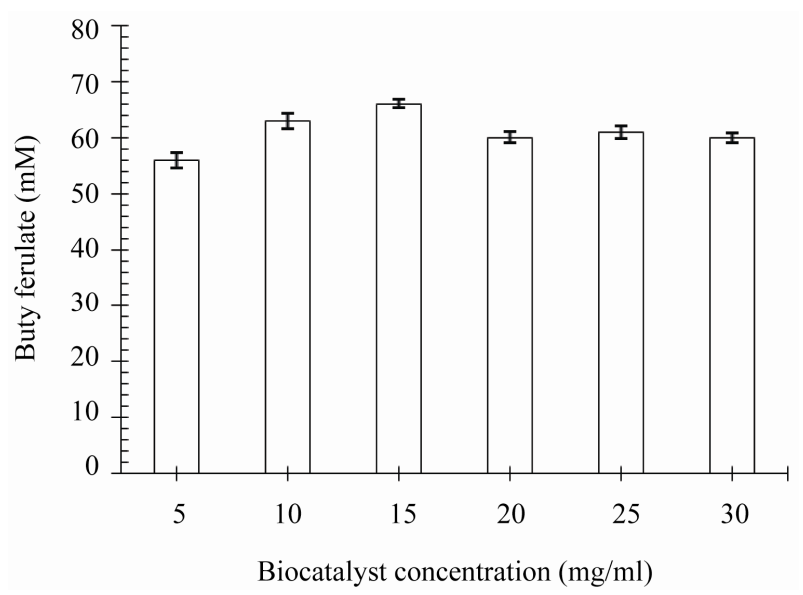

Figure 4. Effect of biocatalyst concentration on synthesis of butyl ferulate. The reaction mixture containing $100 \mathrm{mM}$ butanol and $50 \mathrm{mM}$ ferulic acid and, silica-bound biocatalyst in DMSO was incubated at $45^{\circ} \mathrm{C}$ under shaking for $6 \mathrm{~h}$. 
shows approximately $65 \mathrm{mM}$ yield of butyl ferulate with $15 \mathrm{mg} / \mathrm{ml}$ immobilized enzyme.

\subsubsection{Effect of Temperature on the Synthesis of Butyl Ferulate}

The silica-immobilized lipase performed the esterification reaction much efficiently at $45^{\circ} \mathrm{C}$ with the maximum yield $62 \mathrm{mM}$ (Figure 5). As increase above $30^{\circ} \mathrm{C}$ showed a corresponding increase in the rate of esterification and maximum yield was observed at $45^{\circ} \mathrm{C}$ but any increase in temperature beyond $45^{\circ} \mathrm{C}$ resulted in a decline in the ester synthesis.

\subsubsection{Effect of Salt ions on the Synthesis of Butyl Ferulate}

Among the salt ions; $\mathrm{Cu}^{2+}, \mathrm{Zn}^{2+}$ and $\mathrm{Al}^{3+}$ moderately promoted the ester formation up to $66 \mathrm{mM}$ in comparison to control $62 \mathrm{mM}$ while $\mathrm{Mg}^{2+}, \mathrm{NH}_{4}{ }^{+}, \mathrm{Fe}^{2+}$ and $\mathrm{Ca}^{2+}$ were found to decrease the yield of the butyl ferulate (Figure 6).

\subsubsection{Effect of Molecular Sieves on the Synthesis of Butyl Ferulate}

With increasing the concentration of molecular sieve from $10 \mathrm{mg} / \mathrm{ml}$ to $200 \mathrm{mg} / \mathrm{ml}$ the yield of butyl ferulate elevated marginally to $74 \mathrm{mM}$ in comparison to control $(67 \mathrm{mM})$ when $10 \mathrm{mg} / \mathrm{ml}$ of molecular sieves were used in the reaction mixture (Figure 7). A further increase of the concentration of the molecular sieve from 20 to 200 $\mathrm{mg} / \mathrm{ml}$ resulted in a gradual decrease in synthesis of ester.

\subsubsection{Reusability of Silica-Immobilized Enzyme}

It was observed that the silica-immobilized lipase catalyzed the esterification appreciably for first three cycles after which its activity started to decline (Figure 8). Approximately, $33 \%$ decrease in the ester formation was observed after $4^{\text {th }}$ cycle of esterification.

\subsubsection{Volumetric Scale up of Reaction System for the Synthesis of Butyl Ferulate}

The volume of reaction mixture containing $50 \mathrm{mM}$ : 100 $\mathrm{mM}$ ferulic acid and butanol, respectively was when scaled up from initial $2 \mathrm{ml}$ to 5, 10, 15 and $30 \mathrm{ml}$ with a corresponding increase in the amount of biocatalyst and molecular sieves, a decrease in the amount of ester produced in the reaction cocktail was noticed with a corresponding increase in volume of the reaction system and a lower yield $(32.6 \mathrm{mM})$ was recorded at $30 \mathrm{ml}$ reaction volume (Figure 9).

\section{Discussion}

The exploitation of commercial lipases for preparing value-added specialty products from lipids by esterification/trans-esterification depends on understanding and

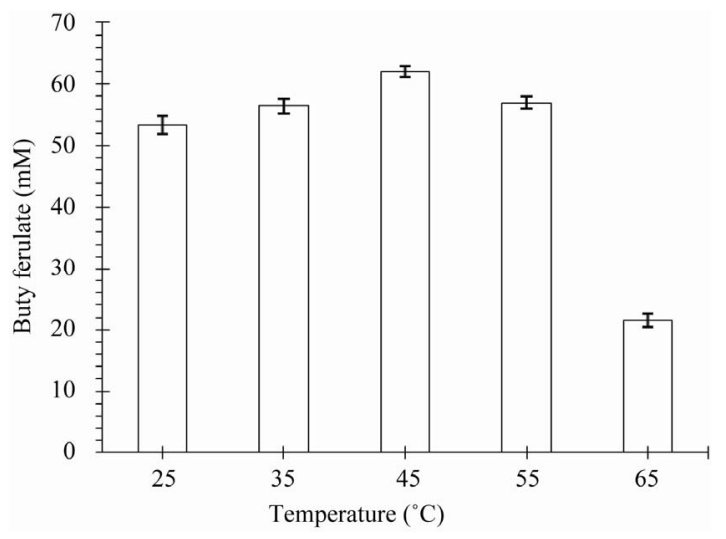

Figure 5. Effect of reaction temperature on the synthesis of butyl ferulate. The reaction mixture containing $100 \mathrm{mM}$ butanol and $50 \mathrm{mM}$ ferulic acid, and silica-bound biocatalyst in DMSO was incubated at stated temperature under shaking for $6 \mathrm{~h}$.

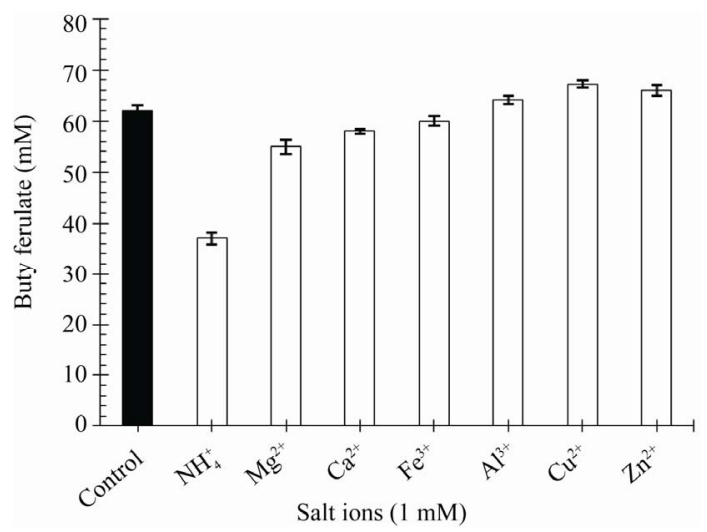

Figure 6. Effect of salt-ions on the synthesis of butyl ferulate. The silica-bound lipase pre-exposed to the selected salt ions $(1 \mathrm{mM})$ for $1 \mathrm{~h}$ at $45^{\circ} \mathrm{C}$ was used to achieve esterification of butanol and ferulic acid (100 mM: $50 \mathrm{mM}$ ) in DMSO at $45^{\circ} \mathrm{C}$ under shaking in $6 \mathrm{~h}$.

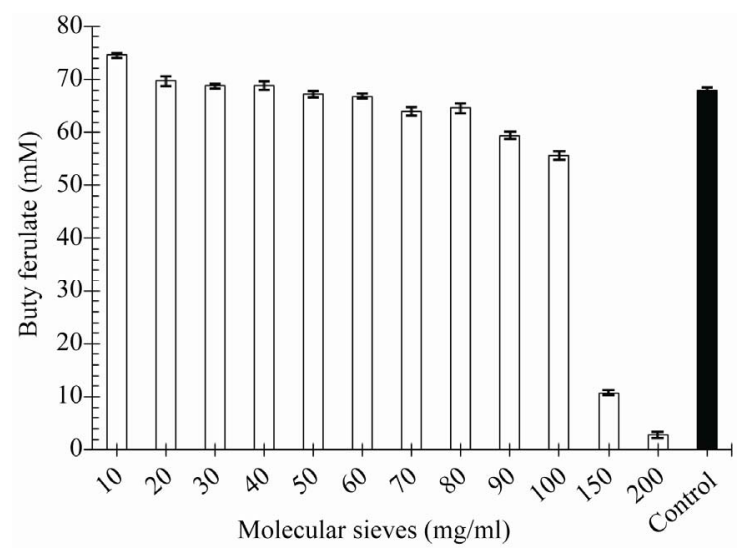

Figure 7. Effect of molecular sieves on the synthesis of butyl ferulate. The reaction mixture containing $100 \mathrm{mM}$ butanol and $50 \mathrm{mM}$ ferulic acid, and silica-bound biocatalyst in DMSO was incubated at $45^{\circ} \mathrm{C}$ under shaking for $6 \mathrm{~h}$. 


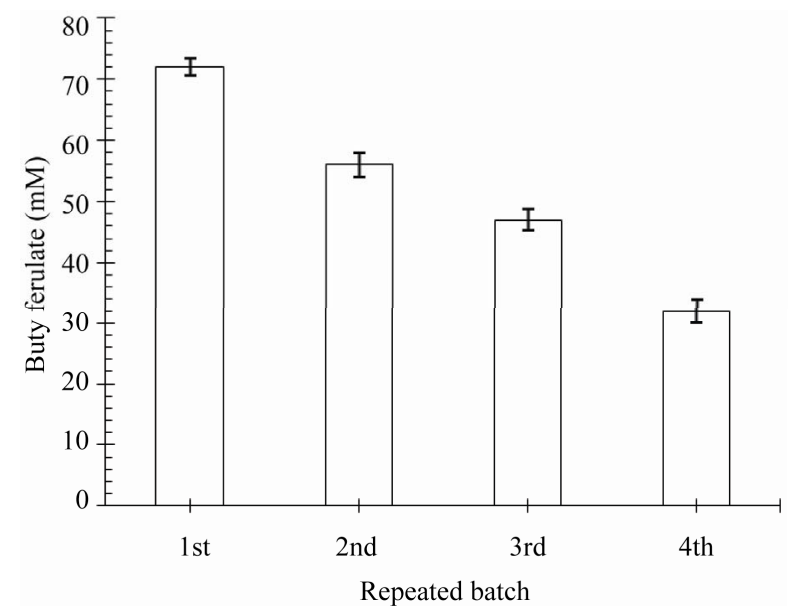

Figure 8. Repetitive synthesis of butyl ferulate by silicabound lipase. The silica-bound lipase was used to achieve esterification of butanol and ferulic acid (100 mM:50 mM) in DMSO at $45^{\circ} \mathrm{C}$ in repetitive cycles of $6 \mathrm{~h}$ each under shaking.

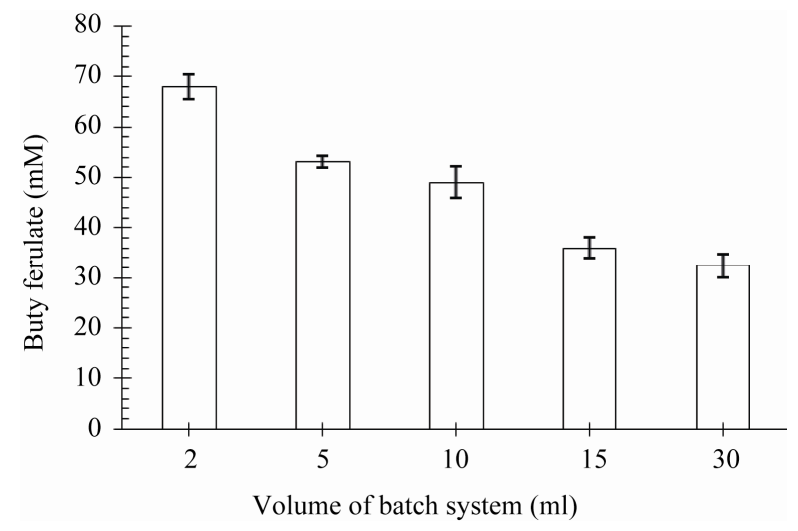

Figure 9. The volume of reaction mixture containing $\mathbf{5 0}$ mM:100 mM ferulic acid and butanol, respectively was scaled up from initial $2 \mathrm{ml}$ to 5, 10, 15 and $30 \mathrm{ml}$ with corresponding increase in the amount of biocatalyst and molecular sieves.

controlling reaction selectivity towards different substrates [21]. Various features of reaction selectivity of lipases are modulated by exogenous factors such as type of organic solvent, choice of co-substrates/reactants, water activity, $\mathrm{pH}$, temperature and nature of support matrix [22-25]. The lipase after immobilization onto silica was exposed to glutaraldehyde that acts as a crosslinking agent and is effective against dilution induced dissociation of enzyme [26]. Glutaraldehyde stabilizes the bound protein (enzyme) onto the silica and maintains the structural integrity as well as its biocatalytic activity. The immobilized enzyme showed maximum hydrolytic activity at $\mathrm{pH} 8.5$ and temperature $45^{\circ} \mathrm{C}$ in comparison to the free enzyme that gave maximum activity at $\mathrm{pH} 8$ and temperature $35^{\circ} \mathrm{C}$. Immobilization, therefore, endowed an effective protection to silica-bound lipase against thermal denaturation and thus possibly facilitates the dispersal of enzyme on a solid surface to provide a far greater interfacial area and accessibility of substrate to the enzyme relative to the use of enzyme powders [27]. The optimum values of temperature, $\mathrm{pH}$, time of reaction, and molar concentration of reactants must be determined to carry out the esterification reaction expecting higher yield [20].

In the present study, the optimal yield of butyl ferulate (64 mM) was obtained at the molar concentration in favor of alcohol (100 mM butanol:50 mM ferulic acid) and optimum temperature for ester formation by silicabound lipase was found to be $45^{\circ} \mathrm{C}$ (62 $\mathrm{mM}$ yield). At lower temperature $\left(25^{\circ} \mathrm{C}\right.$ ), a decreased conversion (43 $\mathrm{mM}$ ) was observed. This suggested that at higher temperature, the conversion rate is controlled by reaction temperature. In contrast, at lower temperature, the reaction rate is limited by mass transport phenomena. Increase or decrease in temperature of reaction mixture might interfere with the porosity, hydrophobic character and diffusion of the reactants and/or products at the catalytic site of the enzyme [28]. In a recent study, the synthesis of ethyl ferulate was carried out at equimolar concentration of ethanol and ferulic acid by celite-bound lipase [29]. Butyl ferulate synthesis increased rapidly during the early stage of reaction $(0-6 \mathrm{~h})$. Moreover, concentration of biocatalyst, molecular sieves and the selected salt ion showed cumulative effect to enhance the yield of butyl ferulate in the reaction system. The immobilized lipase retained more than $50 \%$ of its original activity after $3^{\text {rd }}$ repetitive cycle of esterification. In the present study, the immobilized lipase efficiently catalyzed the esterification of butanol and ferulic acid into butyl ferulate in a short period of $6 \mathrm{~h}$ at $45^{\circ} \mathrm{C}$ under optimized conditions. The bound lipase had a greater stability/activity at enhanced temperature than the free lipase. Temperature had an important effect on the physical state of substrate dispersion also. Higher tem- perature and liquefaction tend to make the substrate more diffusible and hence easily acceptable to the enzyme [30]. But ferulic acid is unstable at high temperatures where it undergoes oxidation [31]. Moreover, in the present study, we have used silica-immobilized lipase to catalyze the esterification of ferulic acid and butanol and interaction among the various parameters was evaluated in such a way to get the maximum yield of ester. In a previous study, lipase immobilized onto on a poly (MAc-coDMA-cl-MBAm) hydrogel showed approximately 94\% binding capacity for lipase. It gave a higher yield for both hydrolysis and esterification for the synthesis of isopropyl myristate as compared to other polymers [32]. The esterification of butanol and ferulic acid by immo- 
bilized lipase was found to be maximum when molar concentration of the hydrophobic reactant; akohol was increased from 1:1 to 2:1 (butanol: ferulic acid) in the reaction mixture. On the other hand, an increase in molar concentration in favor of ferulic acid brought about a decrease in the amount of butyl ferulate synthesized. It appeared that such a decrease in the ester formation might be because of change brought about by excess concentration of ferulic acid that possibly alter the charge distribution at the catalytic site that comprised a triad of serine, aspartic (or glutamic) acid and histidine; serine being a highly conserved residue in immobilized lipase as reported previously in lipase sourced from $\mathrm{Ba}$ cillus spp. BTS-1 [33].

Esterification of butanol and ferulic acid by silicabound lipase in the presence of molecular sieves, and certain salt ions $\left(\mathrm{Cu}^{2+}, \mathrm{Zn}^{2+}\right.$ and $\left.\mathrm{Al}^{3+}\right)$ enhanced the ester synthesis. Water that is often produced as a by-product of the esterification reactions performed by biocatalysts in organic media has several adverse effects on the reaction and enzyme activity/performance. Esterification is generally a water-limited reaction because the equilibrium catalyzed by hydrolytic enzymes is in favor of hydrolysis [34]. Moreover, water inhibits the catalytic reaction besides when an immobilized enzyme with a support which has hydrophilic nature is used, water causes aggregation of support particles [35] resulting in a decreases in the rate of enzyme activity, as seen in the present study. Esterification of butyl alcohol and ferulic acid by silica-immobilized lipase of in the absence of a water scavenger/molecular sieves exhibited approximately 66 $\mathrm{mM}$ esterification. Addition of molecular sieves rise up the esterification rate up to $74 \mathrm{mM}$. The addition of molecular sieves usually improve the equilibrium conversion [36,37] yet in many cases negative effects such as the formation of di-ester and degradation of unstable substrates have also been reported [38,39]. The effect of various salt ions was also studied on the esterification potential of immobilized lipase. $\mathrm{Al}^{3+}$ showing a rise in the yield of butyl ferulate, whereas $\mathrm{Mg}^{2+}, \mathrm{NH}_{4}^{+}, \mathrm{Fe}^{2+}$ and $\mathrm{Ca}^{2+}$ ions have mild inhibitory effect. In a previous study on Burkholderia multivorans V2 the exposure to metal ions such as $\mathrm{Ca}^{2+}, \mathrm{Mg}^{2+}$ and $\mathrm{Mn}^{2+}$ stimulated the lipase activity while $\mathrm{Cu}^{2+}, \mathrm{Fe}^{2+}$ and $\mathrm{Zn}^{2+}$ antagonized the biocatalytic potential of lipase [19]. The inhibitory nature of transition metals has been thought to be due to interaction of ions with charged side chain groups of surface amino acids, thus influencing the conformation and stability of the enzyme [40]. However, in present study $\mathrm{Cu}^{2+}, \mathrm{Zn}^{2+}$ and $\mathrm{Al}^{3+}$ ions were found to have stimulatory effect, which is in contradiction to the above observation, reported earlier [19]. Upon immobilization on to silica, the lipase became quite stable and efficient in retaining its activity up to four cycles of repetitive esterifications.

Further, when an attempt was made to scale up the reaction volume to $30 \mathrm{ml}$ to produce butyl ferulate, strangely any increase in the reaction volume beyond $2 \mathrm{ml}$ resulted in a corresponding decline in the concentration of the ester produced $(32.6 \mathrm{mM})$ in the reaction mixture. It appeared that a simple volumetric increase to achieve the bulk production of the synthesized ester is not possible and some other parameters might affect the rate of esterification in organic solvent system. Thus it might be possible that an increase in the surface area/the area of contact of biocatalyst surface and or enhanced shaking should be explored to see its effect on the increasing yield of the ester in the volumetrically scaled up batch reaction system. The main advantage of enzyme immobilization is the reduced cost because lipase can be repeatedly used to achieve esterification over a couple of fresh cycles of ester synthesis. The silica-bound lipase when repeatedly used to perform esterification under optimized conditions in DMSO resulted in $32 \mathrm{mM}$ butyl ferulate after $4^{\text {th }}$ cycle of esterification.

\section{Conclusions}

In this work, we demonstrated the synthesis butyl ferulate, a medically important ester that is used as an antioxidant/UV blocking agent, antibacterial/anti-fungal agents, cosmetics ingredient and an inducer of apoptosis in mammalian tumor cells. The synthesis of butyl ester was achieved successfully using silica-bound lipase in DMSO in a reaction time as small as $6 \mathrm{~h}$ under optimized conditions of mole ratio, reaction temperature $\left(45^{\circ} \mathrm{C}\right)$ under shaking in the presence of molecular sieves. The silica-bound lipase could be repetitively used to perform esterifications reactions up to $4^{\text {th }}$ cycle. The scale up of optimized reaction system possibly required further optimization of parameters like surface area to volume ration of the reaction system as well as agitation of the reaction cocktail to achieve consistently higher yield of butyl ferulate.

\section{Acknowledgements}

This work has been funded under a Major Research Project F. No. 34-269/2008 (SR) dated Dec. 30, 2008 awarded to one of the authors [SSK] by University Grants Commission, New Delhi, India; and the annual grant sanctioned by Department of Biotechnology, Ministry of Science \& Technology, Government of India to Department of Biotechnology, Himachal Pradesh University, Shimla, India.

\section{REFERENCES}

[1] H. Kikuzaki, M. Hisamoto, K. Hirose, K. Akiyama and H. Taniguchi, "The Effect of Trans-Ferulic Acid and Ga- 
mmaoryzanol on Ethanol-Induced Liver Injury in C57BL Mouse," Journal of Agricultural and Food Chemistry, Vol. 50, No. 7, 2002, pp. 2161-2168. doi:10.1021/jf011348w

[2] J. Chalas, C. Claise, M. Edeas, C. Messaoudi, L. Vergnes, A. Abella and A. Lindenbaum, "Effect of Ethyl Esterification of Phenolic Acids on Low-Density Lipoprotein Oxidation,” Biomedicine Pharmacotherapy Vol. 55, No. 1, 2001, pp. 54-60. doi:10.1016/S0753-3322(00)00011-1

[3] N. Nakatani, Y. Tachibana and H. Kikuzaki, "Establishment of Model Substrate Oil for Antioxidant Activity Assessment by Oil Stability Index Method," Journal of the American Oil Chemists' Society, Vol. 78, No. 1, 2001, pp. 19-23.

[4] L. D. Compton, A. Joseph, A. J. Laszlo and A. M. Berhow, "Lipase-Catalyzed Synthesis of Ferulate Esters," Journal of the American Oil Chemists' Society, Vol. 77, No. 5, 2000, pp. 513-519.

[5] E. Cione, P. Tucci, V. Senatore, M. Perri, S. Trombino, F. Iemma, N. Picci and G. Genchi, "Synthesized Esters of Ferulic Acid Induce Release of Cytochrome $C$ From Rat Testes Mitochondria," Journal of Bioenergetics and Biomembranes, Vol. 40, No. 1, 2008, pp. 19-26. doi:10.1007/s10863-007-9097-7

[6] D.L. Compton, "Sunscreens Based on Vegetable Oil," Lipid Technology, Vol. 17, No. 3, 2005, pp. 276-279.

[7] A. Saija, A. Tomaino, R. L. Cascio, D. Trombetta, A. Proteggente, A. D. Pasquale, N. Uccella and F. Bonina, "Ferulic and Caffeic Acids as Potential Protective Agents against Photooxidative Skin Damage,” Journal of the Science of Food and Agriculture, Vol. 79, No. 3, 1999, pp. 476-480.

doi:10.1002/(SICI)1097-0010(19990301)79:3<476::AIDJSFA270>3.0.CO;2-L

[8] T. Akihisa, K. Tasukawa, M. Yamaura, M. Ukiya, Y. Kimura, N. Shimizu and K. Arai, "Triterpene Alcohol and Sterol Ferulates from Rice Bran and Their Antioxidant Properties," Journal of Agricultural and Food Chemistry, Vol. 48, No. 6, 2000, pp. 2313-2319. doi:10.1021/jf0001350

[9] J. A. Laszlo, D. L. Compton, F. J. Eller, S. L. Taylor and T. A. Isbell, "Packed-Bed Bioreactor Synthesis of Feruloylated Monoacyl and Diacylglycerols: Clean Production of a "Green" Sunscreen," Green Chemistry, Vol. 5, No. 4, 2003, pp. 382-386. doi:10.1039/b302384b

[10] A. Murakami, Y. Nakamura, K. Koshimizu, D. Takahashi, K. Matsumoto, K. Hagihara, H. Taniguchi, E. Nomura, A. Hosoda, T. Tsuno, Y. Maruta, H. W. Kim, K. Kawabata and H. Ohigashi, "FA15, a Hydrophobic Derivative of Ferulic Acid, Suppresses Inflammatory Responses and Skin Tumor Promotion: Comparison with Ferulic Acid,” Cancer Letters, Vol. 180, No. 2, 2002, pp. 121-129. doi:10.1016/S0304-3835(01)00858-8

[11] K. Warner and J. A. Laszlo, "Addition of Ferulic Acid, Ethyl Ferulate, and Feruloylated Monoacyl and Diacylglycerols to Salad Oils and Frying Oils,” Journal of the American Oil Chemists' Society, Vol. 82, No. 9, 2005, pp.
647-652.

[12] A. Zaks and A. M. Klibanov. "Enzymatic Catalysis in Nonaqueous Solvents," The Journal of Biological Chemistry, Vol. 263, No. 5, 1988, pp. 3194-3201.

[13] T. Nishio, T. Chicano and M. Kamimura, "Purification and Some Properties of Lipase Produced by Pseudomonas fragi," Agricultural and Biological Chemistry, Vol. 52, No. 5, 1988, pp. 1203-1208. doi:10.1271/bbb1961.52.1203

[14] U. K. Winkler and M. Stuckmann, "Glucogen, Hyaluronate and Some Other Polysaccharides Greatly Enhance the Formation of Exolipase by Serratia marcescens," Journal of Bacteriology, Vol. 138, No. 3, 1979, pp. 663670.

[15] O. H. Lowry, N. J. Rosenbrough, A. L. Farr and R. J. Randall, "Protein Measurement with the Folin Phenol Reagent,” Journal of Biological Chemistry, Vol. 193, No. 1, 1951, pp. 265-275.

[16] H. J. Chae, M. J. In and E. Y. Kim, “Optimization of Protease Immobilization by Covalent Binding Using Glutaraldehyde," Applied Biochemistry and Biotechnology, Vol. 69, No. 1, 1998, pp. 53-67.

[17] J. M. Palomo, R. L. Segura, G. Fernandez-Lorente, R. Fernandez-Lafuente and J. M. Guisa'n, "Glutaraldehyde Modification of Lipases Adsorbed on Aminated Supports: A Simple Way to Improve Their Behaviour as Enantioselective Biocatalyst," Enzyme and Microbial Technology, Vol. 40, No. 4-5, 2007, pp. 704-707.

doi:10.1016/j.enzmictec.2006.05.026

[18] S. Sun, L. Shan, Q. Jin, Y. Liu and X. Wang, "Solvent Free Synthesis of Glyceryl Ferulate Using a Commercial Microbial Lipase,” Biotechnology Letters, Vol. 29, No. 1, 2007, pp. 45-949. doi:10.1007/s10529-007-9338-1

[19] V. Dandavate, J. Jinjala, H. Kehria and D. Madamwar, "Production Partial Purification and Characterization of Organic Solvent Tolerant Lipases from Burkholderia multivorans V2 and Its Applications for Ester Synthesis," Bioresource Technology, Vol. 100, No. 13, 2009, pp. 3374-3381. doi:10.1016/j.biortech.2009.02.011

[20] M. L. Verma and S. S. Kanwar, "Lipases, Wiley Encyclopedia of Industrial Biotechnology,” Bioprocess Bioseparation and Cell Technology, In: Michael C. Flickinger, Ed., Vol. 5, 2010, pp. 3550-3565.

[21] R. G. Jensen, D. R. Galluzzo and V. J. Bush, "Selectivity is an Important Characteristic of Lipases (Acylglycerol Hydrolases)," Biocatalysis, Vol. 3. No. 2, 1990, pp. 307317. doi:10.3109/10242429008992074

[22] U. T. Bornscheur, C. Bessler, R. Sriniwas and S. H. Krishna, "Optimizing Lipase and Related Enzymes for Efficient Applications,” Trends in Biotechnology, Vol. 20, No. 10, 2002, pp. 433-437. doi:10.1016/S0167-7799(02)02046-2

[23] R. R. Klein, G. King, R. A. Moreau, G. P. McNeill, P. Villeneuve and M. J., Hass, "Additive Effects of Acylbinding Site Mutations on the Fatty Acid Selectivity of Rhizopus delemar Lipase," Journal of the American Oil Chemists' Society, Vol. 74, No. 11, 1997, pp. 1401- 1407. 
[24] J. S. Rhee and S. J. Kwon, "Water Activity Control in Lipase-Catalyzed Reaction System,” Journal of Microbiology and Biotechnology, Vol. 8, No. 3, 1998, pp. 191196.

[25] C. H. Lee and K. L. Parkin, "Effect of Water Activity and Immobilization on Fatty Acid Selectivity for EsterificaMtion Reactions, Ediated by Lipases,” Biotechnology and Bioengineering, Vol. 75, No. 2, 2001, pp. 219-227. doi:10.1002/bit.10009

[26] N. S. Dosanjh and J. Kaur, "Immobilization, Stability and Esterification Studies of a Lipase from a Bacillus sp,” Biotechnology and Applied Biochemistry, Vol. 36, No. 1, 2002, pp. 7-12. doi:10.1042/BA20010070

[27] S. S. Kanwar, S. Gehlot, M. L. Verma, R. Gupta, Y. Kumar, and G. S. Chauhan, "Synthesis of Geranyl Butyrate with the Poly (Acrylic Acid-co-Hydroxy Propyl Methacrylate-cl-Ethylene Glycol Dimethacrylate) Hydrogel Immobilized Lipase of Pseudomonas aeruginosa MTCC4713," Journal of Applied Polymer Science, Vol. 110, No. 5, 2008, pp. 2681-2692. doi:10.1002/app.28241

[28] M. L. Verma and S. S. Kanwar, "Properties and Application of Poly (Methacrylic Acid-co-Dodecyl Methacrylate-cl-N, N-Methylene Bisacrlamide) Hydrogel Immobilized Bacillus cereus MTCC 8372 Lipase for the Synthesis of Geranyl Acetate,” Journal of Applied Polymer Science, Vol. 110, No. 2, 2008, pp. 837-846. doi:10.1002/app.28539

[29] A. Kumar and S. S. Kanwar, "Synthesis of Ethyl Ferulate in Organic Medium Using Celite-Immobilized Lipase,” Bioresource Technology, Vol. 102, No. 3, 2010, pp. 2162-2167. doi:10.1016/j.biortech.2010.10.027

[30] H. Konthanen, M. Tenkanen, R. Fagerstro and T. Reinikainen, "Characterization of Steryl Esterase Activities in Commercial Lipase Preparations,” Journal of Biotechnology, Vol. 108, No. 1, 2004, pp. 51-59. doi:10.1016/j.jbiotec.2003.11.003

[31] M. Tsuchiyama, T. Sakamoto, T. Fujita, S. Murata, S. Kawasaki, "Esterification of Ferulic Acid with Polyols Using a Ferulic Acid Esterase from Aspergillus Niger," Biochimica et Biophysica Acta Subjects, Vol. 1760, No. 7, 2006, pp. 1071-1079. doi:10.1016/j.bbagen.2006.03.022

[32] M. L. Verma, G. S. Chouhan and S. S. Kanwar, "Enzymatic Synthesis of Isopropyl Myristate Using Immobi- lized Lipase from Bacillus Cereus MTCC 8372,” Acta Microbiologica et Immunologica Hungarica, Vol. 55, No. 3, 2008, pp. 327-342. doi:10.1556/AMicr.55.2008.3.4

[33] S. S. Kanwar, M. Srivastva, I. A. Ghazi, S. S. Chimni, K R. K. aushal and G. K. Joshi, "Properties of an Immobilized Lipase of Bacillus coagulans BTS-1,” Acta Microbiologica et Immunologica Hungarica, Vol. 51, No. 1-2, 2004, pp. 57-73. doi:10.1556/AMicr.51.2004.1-2.4

[34] P. J. Halling, "Effects of Water on Equilibria Catalyzed by Hydrolytic Enzymes in Biphasic Reaction Systems," Enzyme Microbial Technology, Vol. 16, No. 11, 1984, pp. 513-516. doi:10.1016/0141-0229(84)90006-1

[35] L. L. Zhao, J. H. Xu, J. Zhao, J. Pan and Z. L. Wang, "Biochemical Properties and Potential Applications of an Organic Solvent Tolerant Lipase Isolated from Serratia marcenscens ECU1010,” Process Biochemistry, Vol. 43, No. 6, 2008, pp. 626-633. doi:10.1016/j.procbio.2008.01.023

[36] S. S. Kanwar, S. Pathak, H. K. Verma, S. Kumar, S. S. Chimni and G. S. Chauhan, "Characteristics of Poly (AAc-co-HPMA-cl-EGDMA) Hydrogel-Immobilized Lipase of Pseudomonas aeruginosa MTCC-4713,” Journal of Applied Polymer Science, Vol. 100, No. 6, 2006, pp. 4636-4644. doi:10.1002/app.23129

[37] S. S, Kanwar, R. K. Kaushal, M. L. Verma, Y. Kumar, G. S. Chauhan, R. Gupta and S. S. Chimni, "Synthesis of ethyl Laurate by Hydrogel Immobilized Lipase of Bacillus coagulans MTCC-6375," Indian Journal of Microbiology, Vol. 45, No. 2, 2005, pp. 187-193.

[38] F. Chamouleau, D. Coulon, M. Girardin and M. Ghoul, "Influence of Water Activity and Water Content on Sugar Esters Lipase-Catalyzed Synthesis in Organic Media," Journal of Molecular Catalysis B: Enzymatic, Vol. 11, No. 4-6, 2001, pp. 949-954. doi:10.1016/S1381-1177(00)00166-1

[39] R. D. Sonwalker, C. C. Chen and L. K. Ju, "Roles of Silica Gel in Poly-Condensation of Lactic Acid in Organic Solvents,” Bioresource Technology, Vol. 87, No. 1, 2003, pp. 69-73. doi:10.1016/S0960-8524(02)00197-9

[40] R. N. Z. R. A. Rahman, S. N. Bahrum, A. B. Salleh and M. Basri, "S5 Lipase: An Organic Solvent Tolerant Enzyme,” Journal of Microbiology, Vol. 44, No. 6, 2006, pp. 583-590. 